\title{
EXCISION OF CALCANEO-NAVICULAR BAR FOR PAINFUL SPASMODIC FLAT FOOT
}

\author{
G. P. Mitchell and J. M. C. Gibson, Edinburgh, Scotland
}

In the adult a painful rigid flat foot with a calcaneo-navicular bar usually requires treatment by triple arthrodesis. In the adolescent also, long-standing deformity or adaptive joint changes may call for triple arthrodesis to alleviate pain. In the younger patient, however, without adaptive joint changes, it is worth considering simple excision of the calcaneo-navicular bar. This has been practised but hitherto no appreciable series has been reported.

In order to determine the indications for surgical treatment the results are reported in forty-one spasmodic flat feet in twenty-eight patients aged from ten to fourteen years with calcaneo-navicular bars operated on by the surgical staff of the Princess Margaret Rose Hospital between 1955 and 1960. The duration of observation varied from four to thirteen years, with an average of six years from operation (Table I).

TABLE I

Onset of Symptoms and Follow-up in this Series

\begin{tabular}{|c|c|c|}
\hline Number of feet & $\begin{array}{c}\text { Age at onset of } \\
\text { symptoms } \\
\text { (years) }\end{array}$ & $\begin{array}{c}\text { Average follow-up } \\
\text { in years }\end{array}$ \\
\hline 1 & 5 & 6 \\
5 & 9 & 11 \\
9 & 10 & 6 \\
12 & 11 & $6 !$ \\
4 & 12 & 5 \\
10 & 13 & 6 \\
\hline
\end{tabular}

The average age when symptoms began was eleven years. One unusual child presented at five and a half years with a painful spasmodic flat foot which, despite conservative treatment, became increasingly rigid until the bar was excised at the age of twelve.

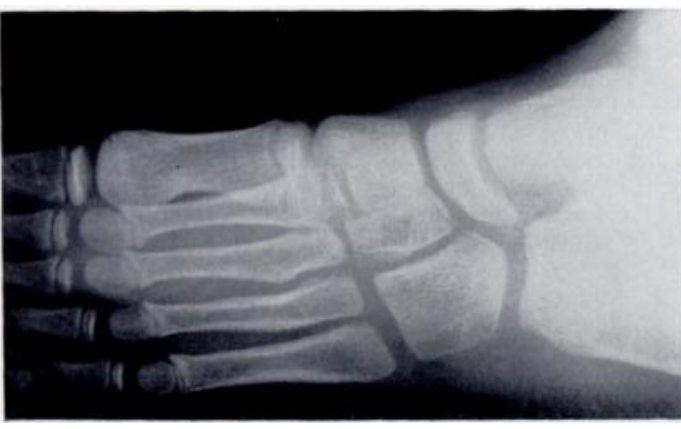

Fig. 1

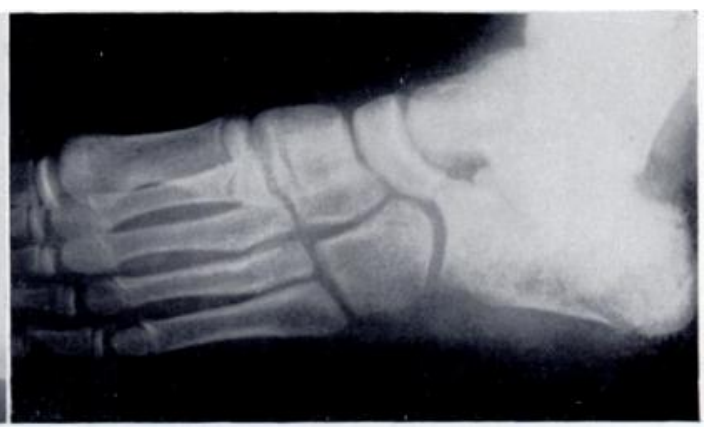

FiG. 2

Figure $1-A$ boy aged 9 years with a mobile painless flat foot. Figure $2-$ Shows the foot two years later, when there was painful restriction of movement caused by calcaneo-navicular bar formation. 
Although the anomaly may begin to develop earlier, movement of the subtalar and midtarsal joints does not usually appear to be restricted until after nine years of age. It may be that after this age ossification of a cartilaginous bar starts (Figs. 1 and 2).

\section{INDICATIONS FOR OPERATION}

It is recognised that even a complete calcaneo-navicular bar may be compatible with a painless non-everted foot. It was shown by Braddock (1961) that painful spasmodic flat foot in children with calcaneo-navicular bars can sometimes be relieved by conservative treatment;

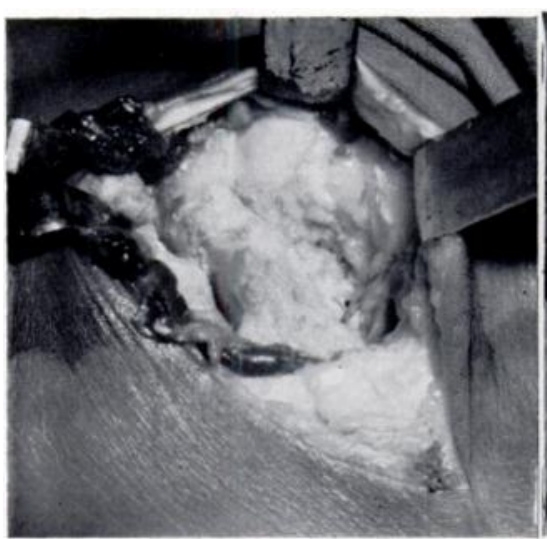

Fig. 3

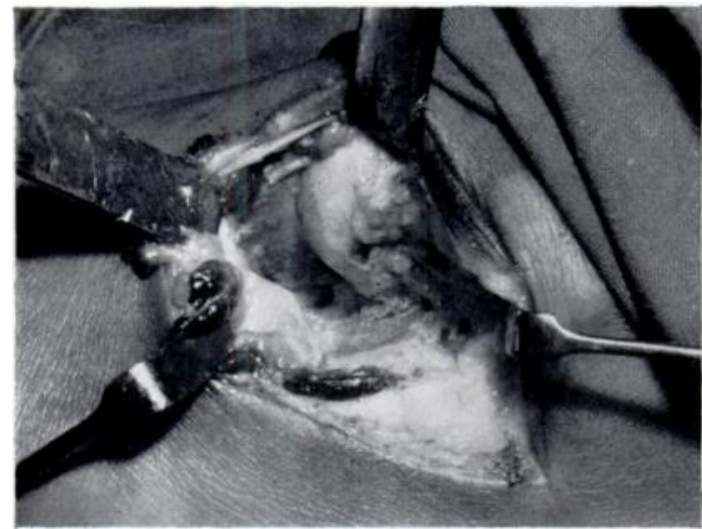

Fig. 5

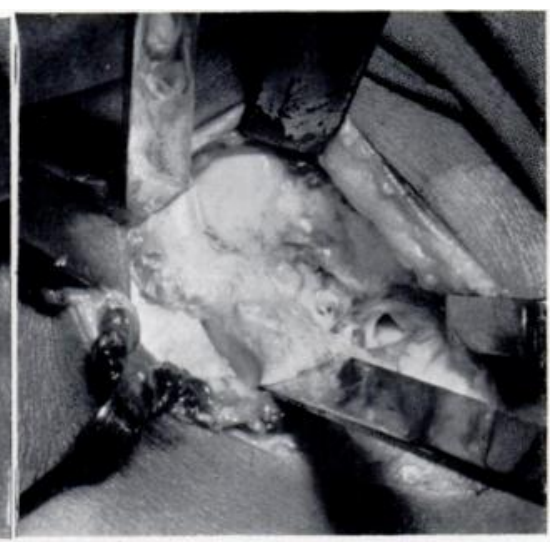

FIG. 4

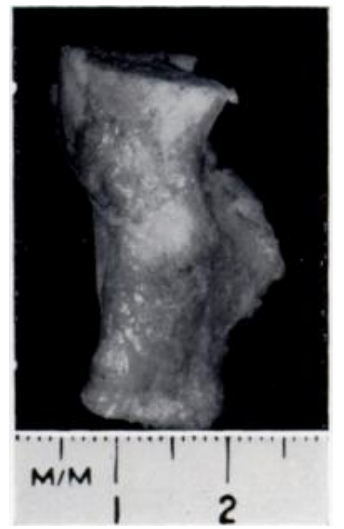

Fig. 6

Figure 3-Lateral view of a left foot at operation showing the talo-navicular articulations and calcaneo-navicular synostosis. Figure 4-Osteotomes show the extent of calcaneal and navicular portions to be excised. Figure 5-The raw surfaces of the calcaneum and navicular bone exposed after excision of the bar. Figure 6-A lateral photograph of the calcaneo-navicular bar after excision.

but in view of the simplicity of operation and the short period of treatment after operation it is suggested that excision of the bar in a rigid and painful foot merits consideration. To be successful, operation should be confined to the younger patient-those under fourteen years of age. Long-standing deformity or adaptive joint changes diminish the chance of success and were responsible for some poor results in this series. The ideal case for operation is that of a young patient with symptoms of recent origin and no adaptive joint changes visible in the radiographs. 
TABLE II

TABLE OF RESULtS

\begin{tabular}{|c|c|c|c|c|c|c|c|}
\hline $\begin{array}{c}\text { Case } \\
\text { number }\end{array}$ & Sex & $\begin{array}{l}\text { Duration of } \\
\text { symptoms }\end{array}$ & Side & $\begin{array}{c}\text { Age at } \\
\text { operation } \\
\text { (years) }\end{array}$ & Result & $\begin{array}{c}\text { Subtalar } \\
\text { movement } \\
\text { (degrees) }\end{array}$ & $\begin{array}{c}\text { Triple } \\
\text { arthrodesis } \\
\text { later }\end{array}$ \\
\hline 1 & Female & 1 year & Right & 10 & Relieved & 30 & \\
\hline 2 & Female & $1 \frac{1}{2}$ years & Left & 10 & Relieved & 35 & \\
\hline 3 & Male & 2 months & Right & 13 & Relieved & 30 & \\
\hline 4 & Male & $1 \frac{1}{2}$ years & Left & $11 \frac{1}{2}$ & Relieved & 30 & \\
\hline 5 & Female & 2 months & Right & $10 \frac{1}{2}$ & Relieved & 35 & \\
\hline 6 & Female & 6 months & Left & 11 & Relieved & 35 & \\
\hline 7 & Male & 2 months & Right & 13 & Relieved & 35 & \\
\hline 8 & Male & 3 months & $\begin{array}{l}\text { Right } \\
\text { Left }\end{array}$ & 11 & $\begin{array}{l}\text { Relieved } \\
\text { Relieved }\end{array}$ & $\begin{array}{l}30 \\
30\end{array}$ & \\
\hline 9 & Male & 1 year & $\begin{array}{c}\text { Right } \\
\text { Left }\end{array}$ & 13 & $\begin{array}{l}\text { Relieved } \\
\text { Relieved }\end{array}$ & $\begin{array}{l}20 \\
20\end{array}$ & \\
\hline 10 & Male & 6 months & $\begin{array}{c}\text { Right } \\
\text { Left }\end{array}$ & 13 & $\begin{array}{l}\text { Relieved } \\
\text { Relieved }\end{array}$ & $\begin{array}{l}25 \\
30\end{array}$ & \\
\hline 11 & Female & 6 months & Left & $10 t$ & Relieved & 35 & \\
\hline 12 & Male & 1 year & $\begin{array}{c}\text { Right } \\
\text { Left }\end{array}$ & 11 & $\begin{array}{l}\text { Relieved } \\
\text { Relieved }\end{array}$ & $\begin{array}{l}35 \\
35\end{array}$ & \\
\hline 13 & Male & $2 \frac{1}{2}$ years & Left & $13 \frac{1}{2}$ & Relieved & 25 & \\
\hline 14 & Male & 3 years & $\begin{array}{c}\text { Right } \\
\text { Left }\end{array}$ & 12 & $\begin{array}{l}\text { Relieved } \\
\text { Relieved }\end{array}$ & $\begin{array}{l}35 \\
30\end{array}$ & \\
\hline 15 & Male & $1 \frac{1}{2}$ years & Left & $11 \frac{1}{2}$ & Relieved & 25 & \\
\hline 16 & Male & $1 \frac{1}{2}$ years & $\begin{array}{c}\text { Right } \\
\text { Left }\end{array}$ & $13 \frac{1}{2}$ & $\begin{array}{l}\text { Relieved } \\
\text { Relieved }\end{array}$ & $\begin{array}{l}5 \\
5\end{array}$ & \\
\hline 17 & Male & 1 year & $\begin{array}{c}\text { Right } \\
\text { Left }\end{array}$ & 12 & $\begin{array}{l}\text { Relieved } \\
\text { Relieved }\end{array}$ & $\begin{array}{l}25 \\
25\end{array}$ & \\
\hline 18 & Male & 6 months & $\begin{array}{c}\text { Right } \\
\text { Left }\end{array}$ & 11 & $\begin{array}{l}\text { Relieved } \\
\text { Relieved }\end{array}$ & $\begin{array}{l}15 \\
15\end{array}$ & \\
\hline 19 & Female & 1 year & Left & $13 \frac{1}{2}$ & Relieved & 30 & \\
\hline 20 & Male & $\begin{array}{l}2 \frac{1}{2} \text { years } \\
1 \text { year }\end{array}$ & $\begin{array}{l}\text { Right } \\
\text { Left }\end{array}$ & $\begin{array}{l}14 \frac{1}{2} \\
13\end{array}$ & $\begin{array}{c}\text { Failed } \\
\text { Relieved }\end{array}$ & $\begin{array}{r}0 \\
15\end{array}$ & $\begin{array}{l}\text { Yes } \\
\text { Yes }\end{array}$ \\
\hline 21 & Female & 1 year & $\begin{array}{c}\text { Right } \\
\text { Left }\end{array}$ & $10 \frac{1}{2}$ & $\begin{array}{l}\text { Improved } \\
\text { Improved }\end{array}$ & $\begin{array}{l}25 \\
25\end{array}$ & \\
\hline 22 & Female & $1 \frac{1}{2}$ years & Left & $11 \frac{1}{2}$ & Improved & 35 & \\
\hline 23 & Male & $\begin{array}{l}6 \text { months } \\
3 \text { months }\end{array}$ & $\begin{array}{c}\text { Right } \\
\text { Left }\end{array}$ & 13 & $\begin{array}{l}\text { Unchanged } \\
\text { Unchanged }\end{array}$ & $\begin{array}{l}0 \\
0\end{array}$ & \\
\hline 24 & Male & 3 years & $\begin{array}{c}\text { Right } \\
\text { Left }\end{array}$ & $11 \frac{1}{2}$ & $\begin{array}{l}\text { Failed } \\
\text { Failed }\end{array}$ & $\begin{array}{l}0 \\
0\end{array}$ & $\begin{array}{l}\text { Yes } \\
\text { Yes }\end{array}$ \\
\hline 25 & Male & 3 years & Right & 12 & Failed & 0 & Yes \\
\hline 26 & Female & 1 year & $\begin{array}{c}\text { Right } \\
\text { Left }\end{array}$ & 11 & $\begin{array}{l}\text { Failed } \\
\text { Failed }\end{array}$ & $\begin{array}{l}0 \\
0\end{array}$ & $\begin{array}{l}\text { Yes } \\
\text { Yes }\end{array}$ \\
\hline 27 & Male & 4 years & Right & $13 \frac{1}{2}$ & Failed & 0 & Yes \\
\hline 28 & Female & 7 years & Right & 13 & Failed & 0 & Yes \\
\hline
\end{tabular}

VOL. 49 B, NO. 2, MAY 1967 
Associated talo-calcaneal anomalies should be excluded by posterior oblique films because they may accompany a calcaneo-navicular bar and may be the primary cause of symptoms.

\section{OPERATION}

Adequate excision of the bar is essential and a sufficient gap must be left after removal of the bar in order to prevent recurrence. The lateral approach is used. The incision starts two fingerbreadths below the lateral malleolus and curves upwards over the calcaneo-cuboid joint to the lateral aspect of the talo-navicular joint. The origin of the extensor digitorum brevis muscle is reflected forwards and the extensor tendons are retracted upwards. The calcaneo-cuboid and talo-navicular joints are opened to expose the calcaneo-navicular bar (Fig. 3). Osteotomes are inserted into the calcaneal and navicular portions of the bar as shown in Figure 4. The lower osteotome is almost horizontal while the upper osteotome is angled downwards. The synostosis is excised with a generous portion of the calcaneal and navicular components (Figs. 5 and 6). The raw bone exposed is cauterised by diathermy. The wound is closed and the foot is immobilised in a below-knee plaster in full inversion for three weeks.

The plaster is removed and after mobilisation the foot is protected by an outside iron and inside $\mathrm{T}$ strap for six months. The $\mathrm{T}$ strap is attached inside the shoe to the lateral side and therefore runs directly under the arch of the foot providing more support than in the conventional position. The management after operation varied somewhat in this series but this was the routine used in Cases 1 to 10 and proved satisfactory.

\section{RESULTS}

The aims of operation are to relieve pain, to restore subtalar and midtarsal movement, and to correct deformity (Table II). The pain was relieved in twenty-eight feet; three were improved, two still had slight symptoms and eight subsequently deteriorated. Satisfactory results were therefore obtained in thirty-one feet and unsatisfactory results in ten feet. Subtalar inversion of over 25 degrees was restored in 58 per cent of feet and good results were usually related to good subtalar movement (Table III).

Recurrence of the bar at the time of follow-up had occurred to a large extent in one-third of the feet and to a slight extent in another third. Incomplete recurrence of the bar can be compatible with a mobile painless foot (Figs. 7 and 8).

In the eight feet which deteriorated after operation there was a long-standing deformity (Figs. 9 to 12) or there were adaptive changes in the tarsal joints before or shortly after operation (Figs. 13 to 15), and the last two cases (Figs. 9 to 15) are good examples of feet in which excision of the bar is unlikely to prove satisfactory. No explanation of failure was

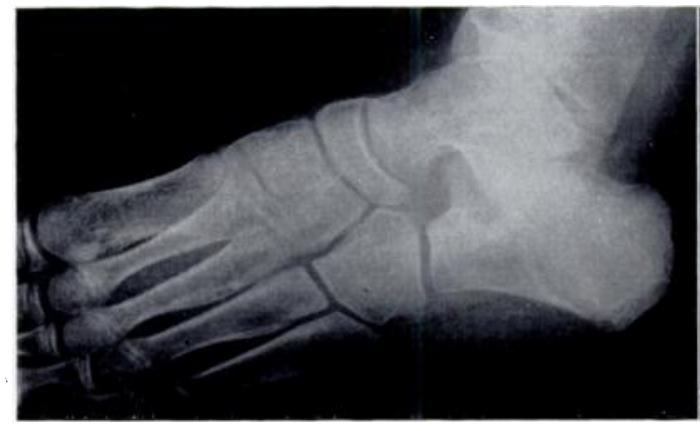

FIG. 7

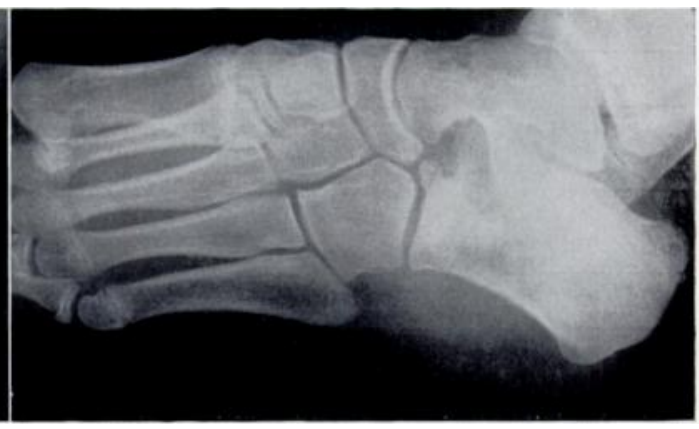

FIG. 8

Case 2-Figure 7 shows adequate excision of a calcaneo-navicular bar. Four years later there has been an incomplete recurrence, as shown in Figure 8, but the result was satisfactory. 


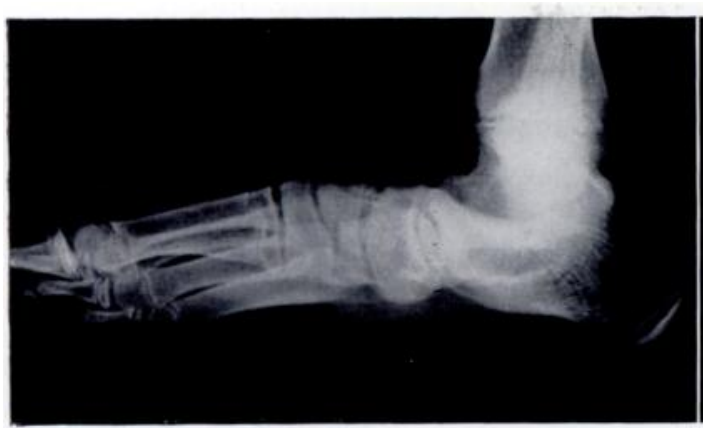

FIG. 9

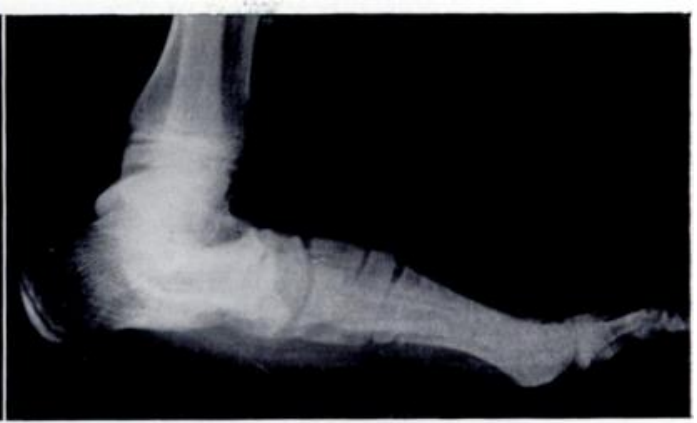

FIG. 10

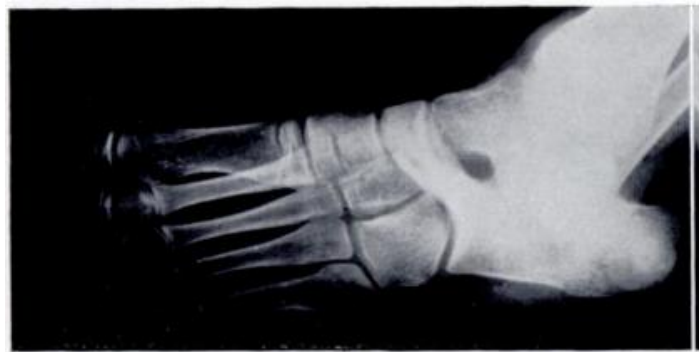

Fig. 11

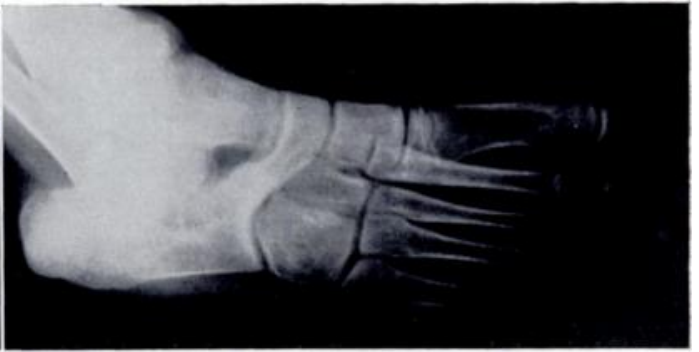

FIG. 12

Case 24-Long-standing bilateral deformity in a boy aged 11 years. Figures 9 and 10 are lateral views of the feet. Figures 11 and 12 are oblique views. Excision of the bar failed.

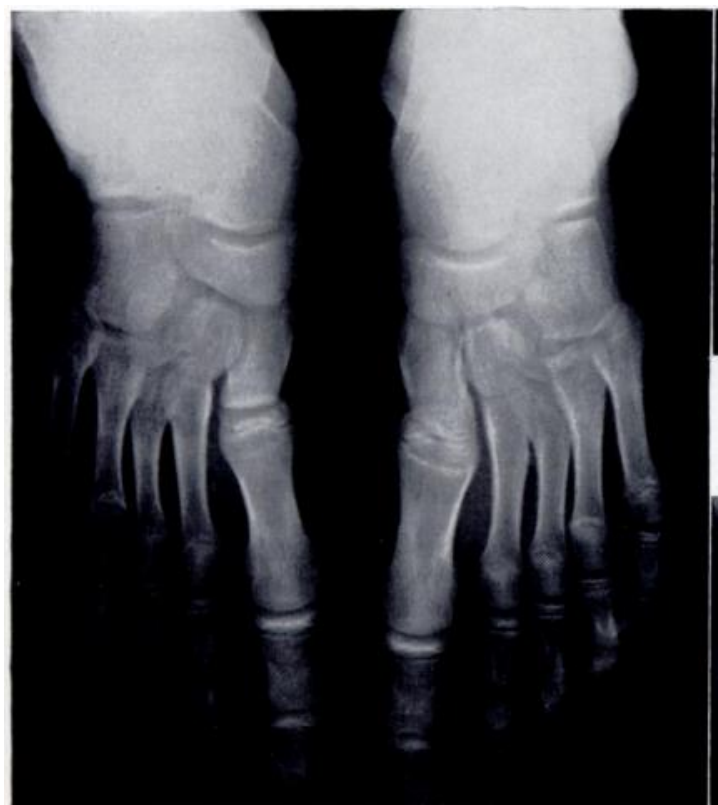

Fig. 13

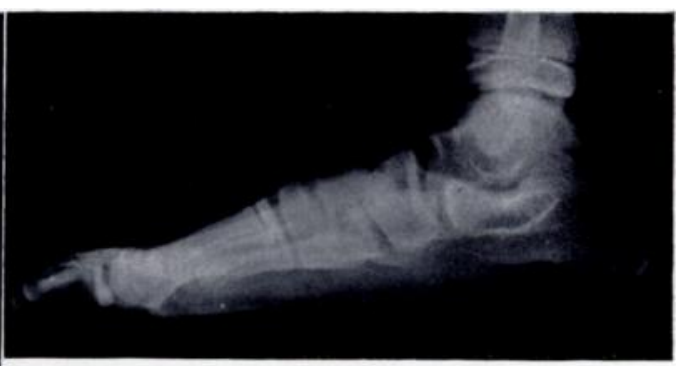

FIG. 14

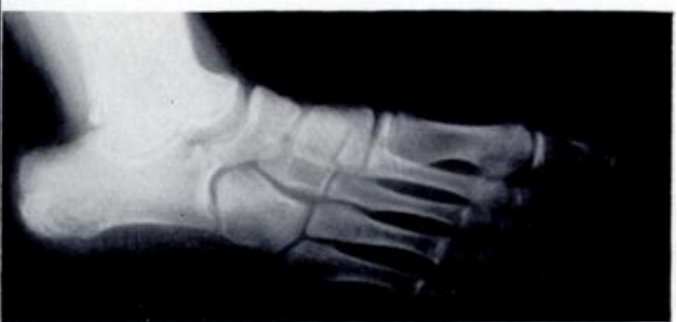

Fig. 15

Case 25. Figure 13-Radiograph of both feet of a boy aged 12 years with a calcaneo-navicular bar and adaptive changes in the right talo-navicular joint. Figures 14 and 15 are other views of the right foot. 
found in one case. In some patients in this series there did not appear to have been any very critical selection for operation. The surgeon had in some cases noted that operation might not prove satisfactory.

Excision of the calcaneo-navicular bar would prove a more reliable and satisfactory procedure if selection were to exclude patients with severe long-standing deformity and with radiological adaptive changes in the tarsal joints.

TABLE III

The Amount of Subtalar Inversion Obtained after Operation Related to Relief of Symptoms

\begin{tabular}{|c|c|c|c|c|c|}
\hline \multirow{2}{*}{\multicolumn{2}{|c|}{$\begin{array}{l}\text { Subtalar } \\
\text { inversion regained } \\
(\text { degrees })\end{array}$}} & \multicolumn{4}{|c|}{ Symptoms } \\
\hline & & Relieved & Improved & Unchanged & Worse \\
\hline Over 25 & . & 21 & 3 & - & - \\
\hline 5 to 20 & . & 7 & - & - & -- \\
\hline 0 & . & - & - & 2 & 1 \\
\hline \multicolumn{2}{|c|}{ Triple arthrodesis } & - & - & - & 7 \\
\hline
\end{tabular}

It is therefore worth considering a small series of ten consecutive patients with thirteen painful spasmodic flat feet of recent origin who were referred to children's clinics in Fife between 1954 and 1960. These patients, who are included in the main series (Cases 1 to 10, Table II) were all operated on by one of us (G. P. M.), the same technique and regime after operation being used in each case.

Because of the supervision of the school medical service there were no patients with symptoms of more than one year and there were no adaptive changes radiologically. All these patients had complete relief of symptoms after excision of the bar, midtarsal movement was

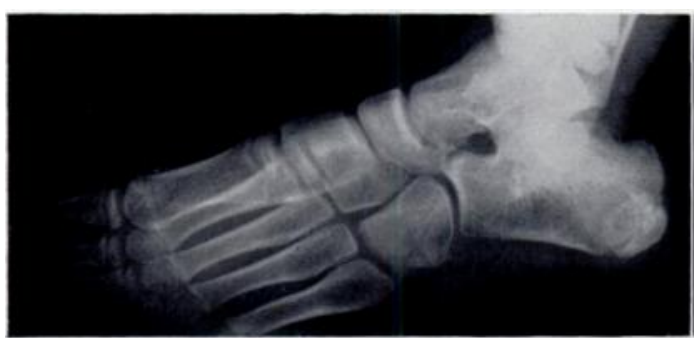

FIG. 16

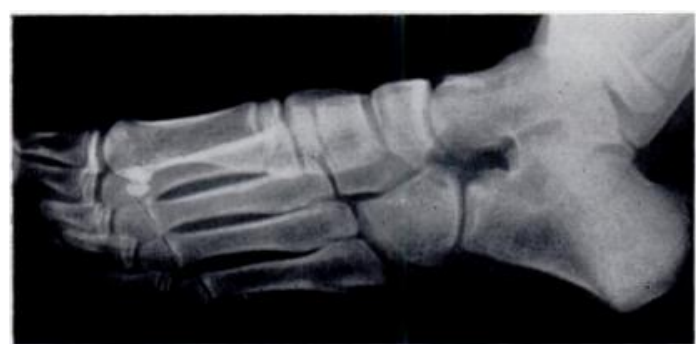

Fig. 18

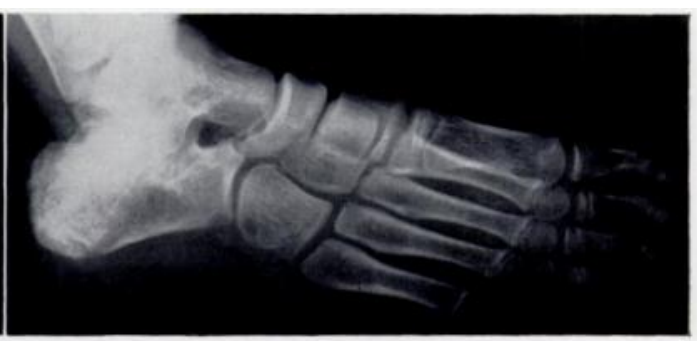

Fig. 17

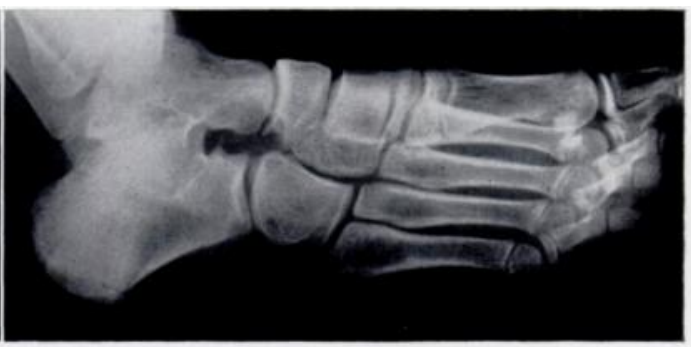

Fig. 19

Case 8-Figures 16 and 17 show bilateral calcaneo-navicular bars at the age of 11 years. Figures 18 and 19 show the feet after excision of the bars. 
restored and subtalar inversion of over 20 to 30 degrees was present in all feet at the average follow-up of six years. Three of the patients had bilateral bars excised at the age of eleven, thirteen and fourteen respectively (Figs. 16 to 19 ).

\section{COMPARISON OF SURGICAL WITH CONSERVATIVE TREATMENT}

Blockey (1955) found that out of eight patients with painful spasmodic flat feet and definite bar formation only one patient remained free from symptoms two years after conservative treatment. Braddock (1961) reported twelve patients between the ages of ten and fifteen years with symptoms from calcaneo-navicular bars who had been treated by plaster immobilisation. When examined twenty years later five of the twelve patients had persistent symptoms and limited inversion was present in eight.

\section{SUMMARY}

1. The results of excision of calcaneo-navicular bars in spasmodic flat feet are reported. The average follow-up was six years. Complete relief of symptoms was achieved in 68 per cent and over 25 degrees of subtalar inversion was restored in 58 per cent of the feet.

2. The results appear slightly more favourable than those of conservative treatment, but it is realised that the period of observation is short.

3. In a selected group of patients operation by a standard technique relieved symptoms and restored subtalar movement in all.

4. It is submitted that excision of the calcaneo-navicular bar is a justifiable procedure in the younger patient with painful spasmodic flat foot of recent origin.

We are grateful to our colleagues at the Princess Margaret Rose Hospital for the inclusion of their cases in the series.

\section{REFERENCES}

Blockey, N. J. (1955): Peroneal Spastic Flat Foot. Journal of Bone and Joint Surgery, 37-B, 191.

Braddock, G. T. F. (1961): A Prolonged Follow-up of Peroneal Spastic Flat Foot. Journal of Bone and Joint Surgery, 43-B, 734. 